\title{
Kłopotliwe dziedzictwo
}

\section{kulturowe na Ziemiach}

\section{Zachodnich i Północnych}

\section{(ekspertyza)}

\section{MARCIN TUJDOWSKI}

Instytut Zachodni im. Zygmunta Wojciechowskiego w Poznaniu

\section{ROCZNIK}

\section{ZIEM}

\section{ZACHODNICH}

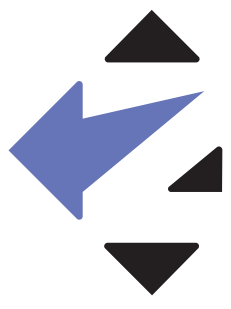


Od lat 90. XX w. samorządy zachodniej Polski prowadzą autonomiczną politykę w zakresie kultywowania pamięci historycznej. Zazwyczaj działania z tego zakresu dotyczą kwestii obecności niemieckiego dziedzictwa kulturowego, przy czym nie wynika to z uregulowań prawnych, a raczej z praktyki wymuszonej okolicznościami. W ciągu ostatnich lat wielokrotnie mieliśmy do czynienia $\mathrm{z}$ incydentami z poniemieckim dziedzictwem w tle. Niestety, praktyka pokazuje, że takie przypadki wciąż się zdarzają i podobnie jak w latach poprzednich, brakuje uregulowań i refleksji post factum.

W czerwcu 2017 r. wybuchł skandal w Kostrzynie nad Odrą. Do rady miasta zwrócił się niemiecki przedsiębiorca Horst Arendt, wskazując, że niemiecki obywatel Karl-Heinz Henschel, uhonorowany parę lat wcześniej medalem za zasługi miasta w czasie wojny, był członkiem Waffen SS. Pomijając motywację informatora, zachodzi pytanie, jak to się stało, że nikt w radzie miasta nie przeprowadził rozeznania na temat uhonorowanej osoby. Co ważniejsze, samorządowcy z Kostrzynia nad Odrą nie widzieli potrzeby zmiany decyzji już po tym, jak dowiedzieli się o przeszłości honorowego obywatela Henschela.

W październiku br. w Świebodzinie, na wniosek społecznego konserwatora zabytków, odmalowano poniemiecki napis na prywatnej posesji. Był to szyld reklamujący dawny zakład krawiecki, zatem napis bez szczególnej wartości historycznej. Co więcej, napis był w zasadzie współczesną stylizacją, ponieważ został odtworzony na nowo (oryginalny napis zlikwidowano jeszcze przed 1939 r.). Sprawie towarzyszyła społeczna dyskusja, w której przeciwnicy renowacji poniemieckiego napisu zostali określeni mianem przeciwników pojednania polsko-niemieckiego. Po burzliwych dyskusjach na łamach lokalnej prasy i mediów społecznościowych napis zamalowano.

Powyższe przykłady z ostatnich miesięcy wskazują, że kontakt z poniemieckim dziedzictwem kulturowym wciąż jest pewnym wyzwaniem dla lokalnych środowisk czy poszczególnych mieszkańców Ziem Zachodnich i Północnych. W latach poprzednich (przed 1989 r.) mieliśmy na tych terenach do czynienia z masowym wypieraniem niemieckiego dziedzictwa materialnego ze sfery publicznej. Obecnie zauważa się zjawisko przeciwne - nawiązania do niemieckiego dziedzictwa są pożądane do tego stopnia, że tworzy się (jak w przypadku Świebodzina) współczesne stylizacje, czyli nowe-stare ślady obecności Niemców sprzed 1945 r. Niestety, często towarzyszy temu nieznajomość historii najnowszej, brak historycznego i politycznego wyczucia.

Na podstawie przytoczonych przypadków, a także wcześniejszych doświadczeń z obszaru Ziem Zachodnich i Północnych, wydaje się, że celowe byłoby stworzenie kompleksowego swoistego „kodu postępowania” (code of conduct) w przypadku kontaktu z niemieckimi czy innymi (np. radzieckimi) treściami symbolicznymi, upamiętnieniami, symbolami itp. na Ziemiach Zachodnich i Północnych. Odbiorcą takiego algorytmu byliby samorządowcy każdego szczebla, nauczyciele, regionaliści, a także inne zainteresowane osoby (np. inwestorzy). Osoby te często nie mają odpowiednich kompetencji ani doświadczenia, które pozwalałyby im uniknąć problemów $\mathrm{z}$ umiejscowieniem takiego dziedzictwa w przestrzeni publicznej. Dotyczy to również usadowienia niemieckiej historii regionu w lokalnych programach nauczania.

Należy wyraźnie zaznaczyć, że chodzi jedynie o określenie sposobu postępowania z kłopotliwym dziedzictwem, a nie o jego ocenę. 